\title{
Den nødstedte August Lorenzen
}

\section{af H.V.Gregersen}

Stænderdeputeret Peter Hiort Lorenzen fra Haderslev, som "vedblev at tale dansk «, måtte opleve megen materiel modgang, og børnene klarede sig kun takket være formuende velyndere. En af sønnerne gik det særlig dårligt. Dr. phil. H.V.Gregersen fortæller hans livshistorie - en beretning om de hårde vilkår $\mathrm{i}$ tiden for velfærdsstaten blev skabt.

For nogen tid siden oplevede jeg, at et par i øvrigt gennem læsning særdeles velorienterede herrer aldrig havde hørt navnet Laurids Skau. Det var ganske vist »oppe i det gamle land «, som man før i tiden sagde her i det sønderjyske. Et navn som August Lorenzen er der derfor helt sikkert ingen, der forbinder noget specielt med og det hverken nord eller syd for Kongeån. Får man derimod oplyst, at August Lorenzen var søn af Peter Hiort Lorenzen, ved man dog, hvor han hører hjemme. Navnet Peter Hiort Lorenzen er vel nok nogenlunde kendt, selv »i det gamle land«. Mange har i deres skoletid hørt, at det var ham, »der talte dansk og vedblev at tale dansk « - eller har de? Den usikkerhed, som spørgsmålet rejser, er prisen for 1968-generationens opgivelse af egne historiske rødder.

Glædeligvis er den yngre generation vel ikke mere helt uden interesse for historien, men den samler sig nok mere om det socialhistoriske end just om det nationalhistoriske, og det er baggrunden for, at jeg vover at drage en menneskeskæbne frem $i$ lyset, der må betragtes som et socialt tilfælde fra årene forud for lovgivningen om offentlige støtteordninger i 1800-årenes sidste årti.

Stænderdeputeret, købmand Peter Hiort Lorenzen (1791-1845) fik i sine to ægteskaber i alt 12 børn, seks i hvert. Men børnedødeligheden var jo stor $\mathrm{i}$ hine tider. Af første ægteskab med Sophie Catharina Sommer (1796-1825) døde to som børn, og af sidste ægteskab med Helena Dorothea Schroeter (1808-53) nåede ligeledes kun fire voksenalderen. Disse fire, hvis morbroder var møller Otto Schroeter på Haderslev vandmølle, gik det alle godt.

Eldst var Sophie (Anna Sophie Catharina) Lorenzen (1828-1920). Hun tilbragte sit liv som "dame $\mathrm{i}$ huset«, om man vil som guvernante, hos den velhavende fynske købmandsfamilie Muus og senere hos sine brødre. Hun nåede inden sin død at opleve genforeningen.

Frits (Johann Friedrich) Lorenzen (1831-1907) gik militærvejen og opnåede at blive generalløjtnant (med Storkors af Dannebrog og Dannebrogs-mand etc.) 
Bedst kendt i sønderjysk historie er Hans Rudolf Hiort-Lorenzen (18321917), uddannet jurist, borgmester i Ekernførde, senere herredsfoged i det sydlige Angel med bopæl i Slesvig; fordrevet fra byen i 1864. I årene 1868-77 var han redaktør med bopæl i sin fødeby Haderslev, dertil sekretær for Hans Krüger, men forlod i 1877 skuffet Sønderjylland for at blive chefredaktør for "Nationaltidende«. Han endte sit liv i Roskilde som stiftsskriver for Sjallands stift og havde personalhistorien som sin særlige hobby.

Den yngste af de fire overlevende af andet agteskab var Mathilde Augusta Lorenzen (1836-1908). Hun blev gift med Bertel Bruun, assessor i Landsoverretten i Viborg og ejer af Rindsholm.

Når det $\mathrm{i}$ borgerlig henseende kom til at gå så godt for Peter Hiort Lorenzens børn af 2. ægteskab skyldtes det $\mathrm{i}$ høj grad den rige familie Muus fra Kerteminde og Odense. Den sørgede for børnenes underhold, men fik da også tre døtre gift med sønnerne, én med Frits og to (da den først gifte datter døde) med Hans Rudolf.

En stor brevveksling gennem mange år vidner om, at børnene i allerhøjeste grad følte sig i taknemmelighedsgæld til Laurids Skau. Det var ham, der efter deres fars død havde virket for, at de to sønner kom ind på Sorø Akademi, og det var også ham, der havde formidlet forbindelsen til familien Muus. Han
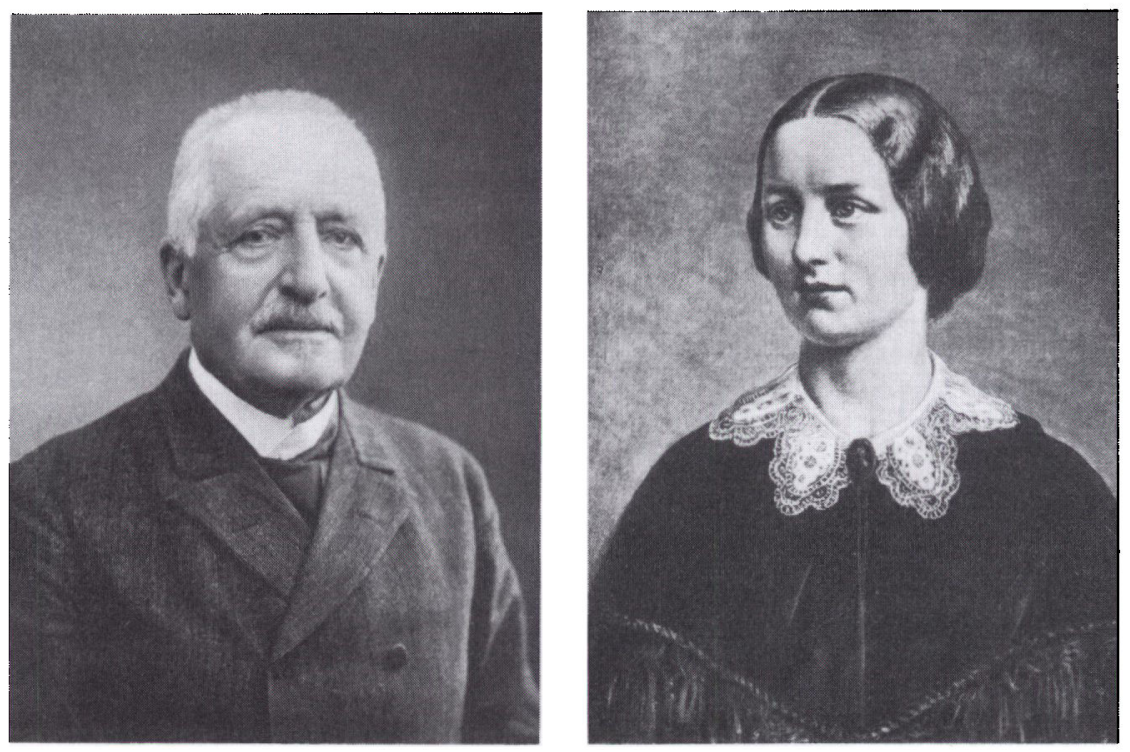

En del portratter og fotos er kendt fra familien Lorenzen. Men sden nodstedte August Lorenzen sager man forgaves - det er de mere heldige familiemedlemmer, man kan finde afbildet. Her ses halvbroderen Hans Rudolf Hiort-Lorenzen (1832-1917) og hans kone Oline Johanne Dorothea Bruun Hiort-Lorenzen fodt Muus (1836-1864). Gengivet efter H. R. Hiort-Lorenzen: Slagten Lorenzen fra Rinkenas (1942). 
var deres rådgiver og hjælper og bevarede dem i kært minde. Endnu en god måneds tid før sin død i 1864 sendte han Sophie Lorenzen et langt brev, der slutter: "Hils nu slægt og venner hjerteligt fra mig og bevar i venlig erindring din altid hengivne Laurids Skau«.

Peter Hiort Lorenzens fire overlevende børn af 1. ægteskab, alle sønner, fik en mere omtumlet skæbne.

Den ældste, Martin, født 1816, nåede som styrmand til Danmarks koloni på Guinea-kysten, det nuværende Ghana, hvor han i 1841 døde af en tropesygdom. I et af sine breve nævner Peter Hiort Lorenzen, at Laurids Skau altid havde mindet ham om denne søn.

De to følgende sønner, Carl Frederik, født 1819, og Thomas, født 1821, endte begge deres dage i U.S.A. De havde været ansat i deres fars kolonialog isenkramforretning i Haderslev, men med fallitten efter Peter Hiort Lorenzens død i 1845 så de ingen anden udvej end at emigrere til landet "med de ubegrænsede muligheder«.

De slog sig ned i Milwaukee i Wisconsin, hvor de startede som købmænd, og her blev de gift med et par søstre, der var indvandret fra Berlin. I 1857 opnåede de borgerskab i deres nye hjemland, og da borgerkrigen mellem Nord- og Sydstaterne begyndte i 1861, meldte de sig som frivillige. Thomas døde i 1864 i Kentucky, antagelig som følge af krigen. Carl Frederik kunne derimod efter krigens afslutning i 1866 vende tilbage til Milwaukee som afskediget "first lieutenant«. Her døde han i 1896.

Den yngste af sønnerne, August Theodor Albert, født 1822, blev herhjemme, hvor han søgte at slå sig igennem, så godt som det lod sig gøre. Han var blevet uddannet ved landvæsenet og var ved sin fars død forvalter på Bygholm ved Horsens. I 1847 tog han til København, hvor han uddannede sig som brændevinsbrænder hos Brøndum, og her var han, til krigen 1848-50 begyndte.

August Lorenzen meldte sig straks som frivillig, og han blev antaget som sergent og i kraft af sin uddannelse fourer med ansvar for regnskab og proviantering. Da han også kunne engelsk, blev han i 1849 med et krigsskib sendt til Dansk Vestindien, hvor han blev skriver ved intendanturen. Hjemvendt blev han i 1850 forvalter på det militære klædedepot i Rigensgade i København.

Samme år blev han gift med en datter af kaptajn og vejinspektør Degen. Brylluppet stod hos Laurids Skau i Hovst, Vilstrup sogn, da kaptajnen var uformuende. Den unge brud var ifølge Skau whæderlig og brav«, og i ægteskabet med August Lorenzen kom der hurtigt en række børn, efterhånden i alt syv.

Egteskabet fik dog ikke August Lorenzen til at falde til ro. Han var utvivlsomt $i$ sine år ved brændevinsbrændingen og som udkommanderet til 
Vestindien lidt efter lidt blevet alkoholiker. Hans løbebane forblev derfor også i de følgende år præget af ustadighed. Ret længe ad gangen lykkedes det ham ikke at blive i de hverv, som han havde påtaget sig.

Lige så snart han havde hørt om Laurids Skaus udnævnelse til amtsforvalter, sendte han ham den 14. september 1852 sin lykønskning. Laurids Skau havde alle dage været en af dem, som han havde kunnet ty til i nødens stund, og lykønskningen blev derfor ledsaget af disse ord: "Gud i Himlen give, at du i din lykke også må have tanke og følelse i dit hjerte for min ulykke. Enten jeg fortjener min skæbne eller ej, så er jeg dog et menneske, der har et stort ansvar. Prisgivet mangel og savn og mig selv overladt, må jeg fortvivle, hvis mine medmennesker glemmer mig. Ved udgangen af denne måned er jeg atter uden brød. Jeg har måttet leje mig en lille lejlighed, men terminen er snart udløbet, og så Gud hjælpe mig!«.

Det ses ikke, hvorledes det denne gang lykkedes at hjælpe August Lorenzen, men et par år senere var det igen galt. Hans halvbroder, Frits Lorenzen, skrev i 1854 herom til Skau: "Min broder August er i en aldeles hjælpeløs tilstand, og det piner mig at se ham gå til grunde«.

Laurids Skau forsøgte at hjælpe ved at henvende sig til kaptajn Thulstrup, gift med Louise Gandil, en søsterdatter af Julie Marckmann, der havde været Skaus nære veninde. Men trods »det stormløb på kaptajnen til fordel for August«, som han ifølge sit svarbrev til Frits Lorenzen havde gjort, lykkedes det ikke at få den nødstedte ansat hos kaptajnen. I stedet var der håb om en plads som inspektør på jernstøberiet i Haderslev, men det indebar, at August skulle flytte bort fra kone og børn i København. Og konen var hans faste holdepunkt. De boede sammen med børnene i et par lejede værelser, men som Frits fortæller - »de ejer aldeles intet, hverken seng eller mad og drikke. Konen er særdeles respektabel. Hun vasker for andre og tjener derfor en smule, men August har intetsteds kunnet finde arbejde, selv om han har tilbudt sig som simpel jordarbejder ved vandværket «.

Hjælpen kom fra familien Muus, der kendte proprietær Holger Christian Petersen fra Dalumgård i nærheden af Odense, og han havde anskaffet sig en større landejendom ved Simrishamn i Skåne. August Lorenzen skulle her som forvalter i 1855 lede nogle engvandingsarbejder, men hans virke blev kun af kort varighed. Denne gang dog uden egen skyld, idet hans godsejer gik fallit under pengekrisen 1857-58.

I en tid, der ikke kendte til et offentligt socialt sikringsnet, måtte August Lorenzen da atter engang gå til private for at få hjælp, og trods al sin nød var han i virkeligheden bedre stillet end så mange andre af sine samtidige, der kom ud for noget lignende. For dem var der kun tiggeriet eller fattiggården at ty til. August Lorenzen havde derimod forbindelser, som han kunne appelle- 
re til. Hans halvsøskende var som nævnt nærmest blevet adopteret af den rige familie Muus, og det blev da enken efter kammerassessor Muus i Bredgade i København, der trådte hjælpende til. En søn af Peter Hiort Lorenzen måtte ikke stå uden hjælp.

I 1858 gav fru Muus ham en billet til Melbourne i Australien. Det var netop i de år, da guldgraverfeberen rasede, og mon ikke August Lorenzen da kunne blive en af de heldige. Altimens blev hans kone og børn i København, og tjente til dagen og vejen ved vask og strygning.

Det var naturligvis ikke let for moderen også at skulle påtage sig børnenes opdragelse. Især var den ældste, der bar sin farfars navn Peter Hiort Lorenzen, et vanskeligt barn.

Laurids Skau henvendte sig derfor til Orla Lehmann for at få denne til at indstille drengen til en portion af det legat til børns opdragelse og uddannelse, som Lehmanns svigerfar, grosserer Hans Puggaard, havde stiftet i erindringen om sine egne vanskelige opvækstvilkår. Laurids Skaus henvendelse lykkedes. Frits Lorenzen melder herom: "Puggaard har definitivt lovet at tage sig af Augusts ældste søn. Tak for Deres ulejlighed med at tale for Puggaard«.

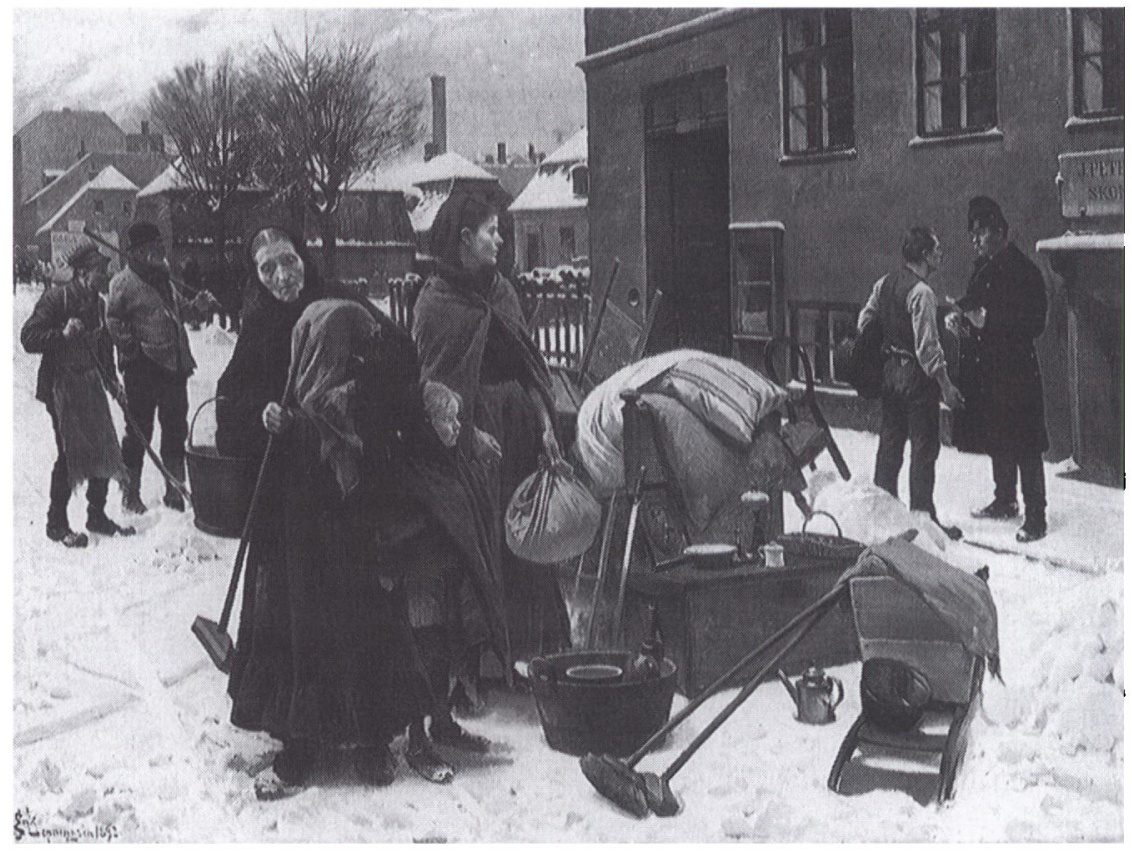

Gang på gang faldt det August Lorenzen svart at skaffe de nodvendige kontanter til at betale huslejen. Situationen på Erik Henningsens socialrealistiske maleri "Sat ud" fra 1892 fik familien tat ind på livet. og kun takket vare velstående beskyttere undgik August Lorenzen samme skabne. Maleriet findes på Statens Museum for Kunst. 
Efter et par år i det fjerne land stod det August Lorenzen klart, at det ikke ville lykkes ham at finde guld. Han længtes hjem til kone og børn. Det var i 1860. Endnu engang fik han hjælp, denne gang til en lille cigarforretning $i$ København. Den lykkedes det ham at drive til 1868 , da han flyttede til Lundtofte. Her tilbragte han som husejer og købmand resten af sine dage. Rejsen til Australien havde været ham en lærestreg. Nu ønskede han at blive bofast; så vidt det stod til ham, for stedse. Hans stakkels forslidte kone døde i 1893, han selv i 1899 .

Deres ældste søn, Peter Hiort Lorenzen, som grosserer Puggaard havde taget sig af, kom ud at sejle som styrmand og deltog som indrulleret i et irsk korps i Englands krige mod Mahdien i Sudan, mod zuluerne i Sydafrika og senere mod boerne i deres krig med englænderne 1899-1902. Hvad der blev af ham, vides ikke! Også det hører med til billedet af de såkaldt "gode, gamle dager.

\section{LITTERATUR}

H.R. Hiort-Lorenzen: Slægten Lorenzen fra Rinkenæs, 3. udg. ved J.F.Gotschalk og Albert Fabritius, 1942.

Laurids Skaus brevveksling med politiske venner i København, udg. af H.V.Gregersen, 1966.

Laurids Skaus brevveksling med politiske venner i Sønderjylland, I-II, udg. af H.V.Gregersen, 1970.

H.V.Gregersen: Sønderjyden Laurids Skaus livsroman, 1992. 